\title{
The mid-level bureaucrats' performance: determinants of their activities and work relationships
}

Pedro luiz Cavalcante

INSTITUTO DE PESQUISA ECONÔMICA APLICADA (IPEA), BRAsílIA - DF, BRAZIL

GABRIELA SPANGHERO LOTTA

UNIVERSIDADE FEDERAL DO ABC, SÃO BERNARDO DO CAMPO - SP, BRAZIL

ERIKa MaYumi Kasai Yamada

EMPreSa de TeCnologia da Informação e Comunicação do MunicíPIO de SÃo PaUlo, SÃo PaUlo - SP, Brazil

\begin{abstract}
Although scholars have been investigating bureaucrats for a long time, mid-level bureaucrats (MLB) have been far less studied in the literature. To fill this gap, this article explores MLBs heterogeneity regarding their profile, professional background and, above all, performance. The main goal is to investigate the determinants of bureaucrats' performance, depicted by two crucial dimensions: the degree of MLBs relationship within public bureaucracy and complexity level of their activities. These skills are valued today with increasing importance in contexts of network governance and bureaucratic responsiveness. First, a descriptive analysis was undertaken of survey data collected in 2014 from federal mid-level bureaucrats in positions filled by appointment. This was followed by formulating synthetic indexes of two dimensions: bureaucrats' activities and their work relationships. Subsequently, multivariate models were employed to explain the determinants of these dimensions. Empirical results show that the mid-level bureaucrats' performance is both affected by the government's structure factors as well as by their own individual characteristics. However, the variables effects vary considerably. The empirical evidence suggests that MLBs tend to be more connected and perform more activities as they hold higher positions filled by appointment, have a higher level of education and capacity to influence decision processes and work directly with policymaking, especially in social policy.
\end{abstract}

Keywords: Public Administration. Mid-level bureaucracy. Federal Government. Brazil.

\section{O desempenho dos burocratas de médio escalão: determinantes do relacionamento e das suas atividades}

\section{Resumo}

Embora os pesquisadores venham estudando a burocracia há bastante tempo, os burocratas de médio escalão (BME) recebem menos atenção da literatura. Para preencher essa lacuna, o artigo explora a questão da heterogeneidade dos BME em relação ao seu perfil, sua experiência profissional e, principalmente, seu desempenho. O principal objetivo é investigar os determinantes do desempenho dos BME a partir de duas dimensões: o nível de relacionamento dos BME e o nível de complexidade de suas atividades. Essas dimensões são muito valorizadas atualmente, considerando o crescimento da sua importância em contextos de governança em rede e accountability burocrática. Primeiro, realizamos uma análise descritiva dos dados coletados em 2014 junto a servidores federais que ocupavam cargos comissionados. Para tanto, elaboramos índices sintéticos das duas dimensões: relacionamento e atividades da burocracia. Posteriormente, empregamos modelos de análise multivariados para explicar seus determinantes. Os resultados empíricos mostram que o desempenho dos burocratas de médio escalão é afetado tanto por fatores estruturais do governo, como também por suas próprias características individuais. No entanto, os efeitos das variáveis mudam consideravelmente. As evidências empíricas sugerem que os BME mais conectados e que realizam mais atividades são aqueles que ocupam cargos comissionados mais elevados. Eles têm maior nível educacional e mais capacidade de influenciar diretamente as decisões dos processos de trabalho e atuam em áreas finalísticas de políticas públicas, especialmente na área social.

Palavras-chave: Administração Pública. Burocracia de Médio Escalão. Governo Federal. Brasil.

\section{El desempeño de los burócratas de nivel medio: determinantes de su relación y de sus actividades}

\section{Resumen}

A pesar de que los académicos han investigado la burocracia por mucho tiempo, los burócratas de nivel medio (BNM) son poco estudiados. Para llenar ese vacío, este artículo explora la cuestión de la heterogeneidad de los BNM en relación con su perfil, experiencia profesional y, principalmente, su performance. El principal objetivo es investigar los determinantes del desempeño de los BNM desde dos dimensiones fundamentales: el grado de relación de los BNM y el nivel de complejidad de sus actividades. Estas habilidades son actualmente más valoradas, teniendo en cuenta el crecimiento de su importancia en contextos de gobernanza y accountability burocrática. En primer lugar, se realizó un análisis descriptivo de los datos de una encuesta realizada en 2014 con funcionarios con cargos comisionados por el gobierno federal. Para ello, se elaboraron índices sintéticos de las dos dimensiones: relación y actividades de la burocracia. Posteriormente, se utilizaron modelos multivariados para explicar sus determinantes. Los resultados empíricos muestran que la performance de los burócratas de nivel medio es afectada tanto por factores estructurales del gobierno como por sus propias características individuales. Sin embargo, los efectos de las variables varían considerablemente. Las evidencias empíricas sugieren que los BNM más conectados y que realizan más actividades son los que ocupan los puestos comisionados más altos. Ellos tienen más estudio y capacidad de influir directamente en las decisiones de los procesos de trabajo, actúan en áreas de terminación de políticas públicas, especialmente en el área social.

Palabras clave: Administración pública. Burócratas de nivel medio. Gobierno Federal. Brasil.

Article submitted on March 30, 2017 and accepted for publication on September 18, 2017.

[Original version]

DOI: http://dx.doi.org/10.1590/1679-395167309 


\section{INTRODUCTION}

This article aims to investigate the complexity of bureaucracy in the Brazilian federal government focusing on a specific set of actors that are highly relevant to the policymaking process, but are less analyzed than others, mid-level bureaucrats (MLB). The article explores MLBs profiles, professional backgrounds and performance in order to understand their heterogeneity. The aim is to investigate the determinants of the bureaucrats' performance, depicted by two important dimensions: the degree of MLBs work relationships and complexity level of activities.

The article is an extension of a comprehensive research initiated in 2014 that intended to deepen the understanding of midlevel bureaucrats of the Brazilian federal government. Quantitative and qualitative data were collected of bureaucrats' profile and performance that supported a variety of published researches, but also raised new questions, given the complexity of the issue. In order to corroborate with this field of study, the article focuses on two central dimensions of MLBs that have not been fully investigated in previous analyzes: work relationships and activities.

The literature outlines the relevance of mid-level bureaucrats' work relationships in establishing horizontal (with peers and other organizations) and vertical (with subordinates and supervisors) relationships. Combined with its manifold performance, the ability to articulate these relationships is a decisive differential in comparison with high-level and street level bureaucrats. MLBs are responsible for connecting different phases of policymaking, primarily formulation and implementation, and they play an important role, often invisible, in achieving results. In this sense, these bureaucrats are central to help in understanding how public administration works.

One very important aspect is the development of these dimensions in the bureaucrats' performance considering the public administration tendencies that highlight the extension of policymaking frameworks and new roles for civil servants both inside and outside the government. The current public sector framework and, subsequently, the bureaucrat's performance are now, after decades of New Public Management's reforms, in line with working in networks and the approach of collaborative governance. Other trend involves the recognition of the multifaceted civil servant, in constant relationship with multiple actors.

In sum, the theoretical assumption is that MLBs are actors who are extremely connected and also perform a variety of activities in policymaking. In this sense, the questions that remain unanswered are: what factors determine the variance on the degree of mid-level bureaucrats' work relationships? What characteristics affect the complexity level of activities performed by MLBs? Are the performance determinants influenced by elements of the government structure, such as the level of hierarchical posts, or by individual features, such as management experience? To address these research questions, survey data collected in 2014 was used, which came from federal mid-level bureaucrats in positions filled by appointment, known as DAS (positions of directors or special advisers). It is worth mentioning that in the structure of positions filled by appointment in the federal government, there are six positions denominated DAS, ranging from DAS1 (lowest) to DAS6 (highest), and NE (Special Nature Positions) that are superior to DAS6. Considering this structure, the civil servants fit into four groups: a) civil servant without DAS (civil servant who is not in a position filled by appointment), considered as low level bureaucrat; b) civil servants in positions from DAS1 to DAS5, considered mid-level bureaucrats (subject of this research); c) DAS6 and NE considered highlevel bureaucrats. The sample counts over 7,000 respondents, which is quite significant, being about $30 \%$ of the population, and representative of different segments (ENAP, 2014).

For the methodology, descriptive statistics were employed to explore the MLBs heterogeneity in several dimensions. Then, synthetic indicators were formulated in order to measure MLBs' performance through the degree of their work relationships and the complexity of their activities (Index of MLB Relationships - IBR and Index of MLB Activities - IBA). Next, a regression model was used to explain determinants of their performance.

The empirical results indicate that the degree of MLBs work relationships and the complexity level of their activities tend to increase depending on the position they occupy, their working area and influential capacity.

Additionally to this introduction, the article provides a theoretical discussion in order to contextualize mid-level bureaucrats' characteristics and performance. In the empirical section of the article, the results of the exploratory analysis are shown and IBR and IBA descriptive statistics are explored. Then, multivariate model estimates are discussed, followed by the final remarks. 


\section{FURTHER RESEARCH ON MID-LEVEL BUREAUCRACY}

Over the last decades, the literature on public policy and public administration has made considerable advances in understanding the role of bureaucrats in the policymaking process. However, the field of study has mainly focused on the so-called high level and street-level bureaucrats. Although the literature assumes the relevance of mid-level bureaucrats, primarily inspired by the long tradition of private managers, there have been few (especially empirical) concrete advances regarding the understanding of managers' characteristics in public administration. In addition, even less research has been dedicated to study the different types of MLBs operating in specific contexts.

Recently, efforts have been made to theoretically conceptualize mid-level bureaucracy and empirically analyze its performance. In an extensive review of the national and international publication about mid-level bureaucracy, Lotta, Pires and Oliveira (2014) showed that the literature has made some progress, but there are still several gaps that must be filled.

Among the issues that deserve further theoretical and empirical studies are the similarities and differences between mid-level bureaucrats. Despite the fact that there is certain consensus about the conceptualization of mid-level bureaucrats - such as having a boss and subordinates, and they are in the middle of the hierarchical structure - each context involves very different realities that affect who MLBs are and what they actually do. This happens because, as the organizational settings are quite different from each other, it is not always clear what is an 'intermediate' position, which is a concept that varies considerably according to the context. As highlighted by Cavalcante and Lotta (2015, p. 302),

[...] the complexity, characteristics and nature of the policies and organizations generate different forms of MLBs activities and performance. Thus, to understand this particular actor, it is essential to analyze the institutional environment in which they are operating.

In this sense, one of the pressing tasks is to investigate the types or groups of MLBs, which may help to understand who MLBs are and what they do. A way to conduct this investigation is to focus on their unique features, such as:

i) proximity or distance to street-level bureaucrats and, therefore, proximity or distance to the service delivered to users;

ii) proximity or distance of bureaucrats that occupy positions in the higher echelons and therefore some degree of exposure to political decisions;

iii) locus of organizational performance - management or policymaking areas.

The ways these variables relate and correlate may have different effects on the profile and performance of mid-level bureaucrats in issues such as internal or external interaction; degree of discretion; scope of their decisions; technical nature of their decisions; isolation or exposure to political issues, etc.

When it comes to public bureaucracy studies, technical and political dichotomy is elements that seem to explain to a large extent the bureaucrats' performance. MLBs simultaneously carry out technical and managerial activities and other technical and political activities, acting to transform strategic decisions (policies) into operational activities (technical) (WILSON, 1968; KAUFMAN, 1960; DALTON, 1959; CHETKOVITCH and KIRP, 2001; OLIVEIRA, 2009; PIRES, 2011). Many authors see this dichotomy between strategic decision and operational activities as a weak point of public policy analysis, first because it is very difficult to categorize what is technical and what is political. Second, due to the failure to empirically observe how decisions that come from political actors are incorporated and transformed by the bureaucrats (HOWLETT, 2011; DEMIR and REDDICK, 2012). The advance of the literature depends, therefore, on deepening the analysis of these different dimensions regarding the bureaucrats' daily work.

Another central element of MLBs' work is the ability to influence decisions. In this sense, some scholars have investigated what features are necessary to foster MLBs' capacity to influence the decision-making process. They conclude that the determinant variables of MLBs influence are the combination of technical and specialized abilities and management skills (KELLY and GENNARD, 2007); position in the organizational structure; level of conflict with the professionals that are responsible for daily operations (CURRIE and PROCTER, 2005); sensitivity to understand the strategic context of the organization (KURATKO, IRELAND, COVIN et al., 2005).

In classic studies about managers, the relational dimension is present, researchers have recently emphasized this theme as central to understanding mid-level bureaucrats' performance. Part of the literature has focused on the importance of the negotiating, articulating and mediating skills that these bureaucrats have. Some scholars, for example, outline that mid-level bureaucrats have historically migrated from more technical functions to others more focused on negotiation and conflict management (CHAREANPUNSIRIKUL and WOOD, 2002). Others argue that these changes have taken MLBs to work with 
emphasis on interpersonal contact activities, dialogue and leadership, instead of management of activities related to routine processes and bureaucratic controls (VIE, 2010).

As already mentioned, the importance of better understanding this segment is in the fact that mid-level bureaucrats are the link between the bureaucrats in the high echelons and the policy implementers. Their role is to connect policy phases - from formulation to implementation - and this connective logic and relational activity is the main difference between MLBs, top officials and the operational level. In order to become effective, however, it is essential to understand MLB's performance from the relationships established with superiors, subordinates or other actors involved in policy.

Lotta, Pires and Oliveira (2014) argue that the interest of relational analysis has strongly emerged more recently. Among the questions in this analytical perspective, it is worth stressing that [...] how these bureaucrats interact with a network of actors that are internal and external to the State; how they influence and regulate the relations of the policy operators themselves; how they mediate and mobilize the relation between formulation and implementation, and so on. In short, they conclude that such actors are a fundamental link between the rules and their enforcement in practice, between the world of policy and the final implementer who has a direct relationship with the end user, between the multiple agencies and their various understandings, in order to construct a consensus around the respective public policies" (LOTTA, PIRES and OLIVEIRA, 2014, p. 41-42).

Lotta, Pires and Oliveira (2014) argue that the interest of relational analysis has strongly emerged more recently. Among the questions in this analytical perspective, it is worth stressing:

"[...] How these bureaucrats Interact with a network of actors that are internal and external to the State; how they influence and regulate the relations of the policy operators themselves; how they mediate and mobilize the relation between formulation and implementation, and so on. They (the questions) consider that these bureaucrats are a fundamental link between the rules and their enforcement in practice, between the world of policy and the final implementer who has a direct relationship with the end user, between the multiple agencies and their various understandings, in order to construct a consensus around the respective public policies" (LOTTA, PIRES and OLIVEIRA, 2014, p. 480).

The relational dimension of MLBs is central, therefore, to explain their performance, as supported by Kuratko, Ireland, Covin et al. (2005), communication issues, structural position and interactions, differentiate MLBs from other actors and strategically position them in the decision making process (KEISER, 2010). It is also important to understand how the state operates from the inside, especially in times when there is coexistence among bureaucratic, managerial and governance models in public administration

The literature demonstrates that the performance of bureaucrats in terms of work relationship has a double axis: horizontal (with peers) and vertical (with superiors and subordinates) (PIRES, 2015). Based on this double performance, MLBs become the "keepers" of key information, communication regulators and of their own relationships.

Middle-level bureaucrats occupy the intersections of the sector-based dynamics and the centralized decision making spheres and maintain flows of monitoring information in one direction and capacity building in the other. They build or produce their positions by managing those information flows. They can intensify or relax their demands for information, decide what will be passed on upwards and what will not, decide to what extent they will make an effort to provide support or seek solutions in response to requests (demands) from partners in other government bodies, decide how best to handle the tensions amongst the various actors with whom they interact and administer whatever measures or referrals they think are necessary. In their own words, they "make the wheels go round" oiling the cogs of the lateral and vertical axes of a complex political-administrative machine (PIRES, 2015, p. 224).

In this sense, Huising and Silbey (2011), for instance, argue that MLBs manage the existing gap between rules and enforcement capacity by employing different practices that allow them to reach the desired results - such as adaptations and translations of the rules, synthesis of learning and so on. Keiser (2010) also uses the idea of work relationships regulation to support that MLBs - grounded on the interactions they establish - build consensus among a variety of actors to achieve their objectives. Johansson (2012) argues that these agents act as "trading managers", and Bevir and Rhodes (2010), say that they act developing trading methods with different agencies and interests for making effective policies.

It is worth mentioning the seminal work of Mintzberg (1973) addressing the idea that activities performed by managers are diverse, so they should be analyzed in three general categories of functions: interpersonal, informational and decisional. Notwithstanding, Mintzberg's categorization seems suitable for the private sector, while it is still necessary to redefine these categories in the public sector. 
This is even more important in a context of changes in the public administration and, consequently, in the bureaucrats' performance, considering years of reforms based on New Public Management (NPM) assumptions. The NPM movement began by focused on search for efficiency and cost reduction, and fostering competition among agencies (POLLITT and BOUCKAERT, 2011). Lately, the reforms incorporated trends of accountability and transparency in their guidelines. After three decades of the managerial movement, a consensus prevails that NPM reforms have led governments to a variety of broad and narrow results that may also be recognized as different models (POLLITT and BOUCKAERT, 2011; OSBORNE, 2010; CHRISTENSEN and LAEGREID, 2007). The current management agenda indicates that instead of an excessive appreciation of the private sector's role concerning service provision, as the first generation of NPM advocated, the new models established a balanced pattern between government, market and civil society.

On one hand, new reform projects strengthen the leading role of public administration, primarily, the focus on the bureaucrats' capacity to work with a more interactive relationship with society and market than the classical bureaucratic standards. In this sense, public administration has modernized the traditional state apparatus in order to make it more professional, more efficient and responsive to citizens (POLLITT and BOUCKAERT, 2011). On the other hand, the public sector tends to function grounded on governance or network governance which advocates the expansion of relationships between all actors within the public administration, that is, between state and society, private actors and government or society and the private sector. In other words, the main assumption is to make the government better informed, more flexible and less exclusive. The hierarchical organization is replaced by the inclusion of new actors in networks directly involved in policymaking and public control (OSBORNE, 2010; POLLITT and BOUCKAERT, 2011).

In sum, these post-NPM perspectives are grounded on the hybrid concept that public administration reinforces the role of the state in the delivery of public services, but takes into account that the capacity of bureaucrats tends to grow when combined with other society actors, both in decision-making and controlling processes, under the "Era of Governance". The current debate is highlighted by a focus on multiple and common goals, rather than the narrow focus on results and performance targets. The leading trends push the bureaucrats to more diversified and interactive performance that encompasses premises of networking, partnerships, collaboration and social participation, together with the previous values of transparency, accountability and efficiency (GREVE, L/EGREID and RYKKJA, 2016; MENICUCCI and GONTIJO, 2016; FOSSEST ØL, BREIT, ANDREASSEN et al., 2015). This means that one of the main factors in the state's performance, in this new context, involves the ability of the bureaucrats to establish and manage relationships.

Based on the categorization proposed by Mintzberg, it can be considered in this context, that there is a tendency for increased activities focused on interpersonal relations. Hence, the interpersonal category, which falls into the roles of promoting interactions, is central for explaining the MLBs role. The literature indicates the importance of the relational skills, the increasing demands for managers performing several activities, as well as giving some clues about the articulating characteristics of these bureaucrats (HUISING and SILBEY, 2011; VAKKURI, 2010; ALEXANDER, LEWIS e CONSIDINE, 2011; KEISER, 2010). However, there is a gap in theoretical and empirical-based knowledge regarding the factors that affect mid-level bureaucrats' performance.

Considering the issue relevance, this article goes on to investigate the determinants of the degree of work relationships and activities of the Brazilian mid-level bureaucrats.

\section{IS THERE ONE OR ARE THERE MANY TYPES OF MLBS?}

One of the main perceptions in the literature is that mid-level bureaucrats are heterogeneous, taking into account their profile, professional background and performance, as well as organizational sector, hierarchic levels and assigned responsibilities. With this in mind, the first question is: to what extent are MLBs different from each other in terms of profile, activities and responsibilities about public policies? Before presenting the descriptive statistics, it is important to discuss some aspects of the survey data used.

The survey on mid-level bureaucrats working in the federal government was undertaken by the National School of Public Administration (ENAP), Federal University of $A B C$ (UFABC) and the Institute of Applied Economic Research (IPEA) from April to June of 2014. The survey questions, focused on profile, professional background and performance, and they were formulated and discussed by a pool of scholars and practitioners from different institutions and government organizations, theoretical 
grounded on bureaucracy literature. The survey used an online platform to collect individual self-applied responses from the target audience - the occupants of positions filled by appointment, also known as DAS (posts of directors or special advisers) ${ }^{1}$. Given that the focus is the middle echelons of the federal bureaucracy, the survey contemplated positions at DAS levels from DAS1 to DAS5. This represents the intermediary segment that is hierarchically situated between the top level of the Executive branch (secretaries, executive-secretary and ministers) and the majority of civil servants (approximately 96\%) who do not have DAS posts. Box 1 below sets out details of the hierarchical levels of those positions as well as the most common functions associated to them.

\section{Box 1}

\section{Hierarchic levels and functions of DAS positions in the Federal Government}

\begin{tabular}{cll}
\hline Hierarchical & \multicolumn{1}{c}{ Executive } & \multicolumn{1}{c}{ Functions } \\
& Minister's Chief of Staff & \\
& Head of Department & \\
& & Minister's Special Advisor \\
DAS 5 & Legal Advisor & \\
& Unternal Control Secretary & \\
DAS 4 & General Coordinator & Advisor \\
DAS 3 & Coordinator & Technical Advisor \\
DAS 2 & Head of Division & Assistant \\
DAS 1 & Head of Section & Technical Assistant \\
\hline
\end{tabular}

Source: Elaborated by the authors.

The survey results were published by the National School of Public Administration (ENAP, 2014) and they provide details of all dimensions of the research. The units of analysis were the MLBs' answers to the survey. More than 9,000 civil servants responded the survey, but after sorting the data, excluding the missing cases, the dataset reached around 7,200 respondents or almost $30 \%$ of the population of civil servants in positions DAS1 to DAS5. The distribution of the respondents is quite representative of the researched population. In other words, when disaggregated by DAS, policy sectors and job attachment (career civil servants and appointees), the percentages in the sample are highly similar to the percentages found in the population (ENAP, 2014). The data from the MLB's sample allows confirming a high degree of heterogeneity of the mid-level bureaucrats in the Brazilian federal government, considering several characteristics. To investigate this, an exploratory descriptive analysis was applied to all variables of the multivariate models that will be discussed in the next section, including those related to government structure and to individual factors. Beginning with the former, Figure 1 below encompasses the mean of the individual variables. On average, the respondents are 44 years old, with almost 15 years of public service and 7 years leading a team (managerial position). The figures show that the majority (61.5\%) do not have capacity to influence policymaking in their organizations, a result based on the survey question on how frequently the MLB's ideas are considered in the decision-making process. Regarding the educational level, the survey data confirm the already well-known information that MLBs, on average, have high levels of education. Almost $94 \%$ of them hold a degree, while over $61 \%$ hold a post-graduate degree.

${ }^{1}$ DAS positions are occupied by both career civil servants and appointees. Decree $n=5.497$ reserves different percentages of DAS positions levels DAS1 to DAS4 exclusively for career civil servants. 
Figure 1

Years of Experience, Influence and Level of Education

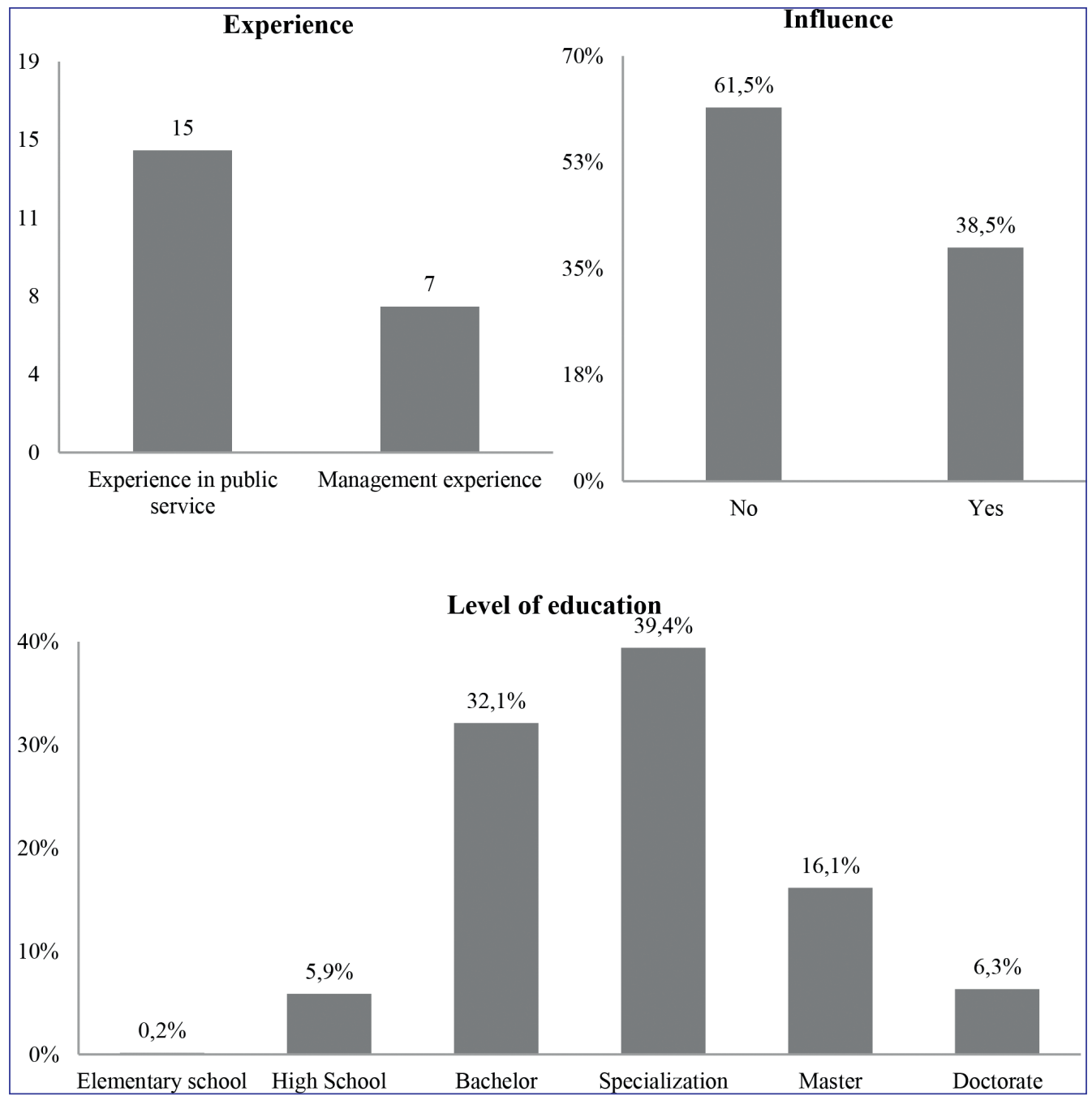

Source: Elaborated by the authors based on Mid-level Bureaucrats Survey.

These findings suggest that the context of policy formulation and implementation demands a specific bureaucrat profile, with a lot of experience and high level of education. This is in line with a more general expectation of the complexity of public policies in recent years, as demonstrated in the literature, and with the professionalization of the bureaucrats (CAVALCANTE and CARVALHO, 2017).

The second group of variables reflect aspects of the government structure, i.e. they are linked to the institutional framework of the state; hence they are not a result of personal features of the bureaucrats. Regarding the policy sector in which MLBs work in the federal government (ENAP, 2014) - these professionals are distributed as follows: i) central bodies (29.5\%); social (28.7\%); economic (19.3\%) and; infrastructure (19.3\%). Figure 2 shows the distribution of four dichotomous variables. It can be seen that (with similar percentage over $75 \%$ in both cases), the majority of MLBs in the survey are civil servants with permanent contracts and work in executive positions instead of advisory positions. Also as expected, 2/3 of the respondents work in the country's capital (Federal District). A more balanced distribution is seen between MLBs directly in charge of policymaking (54\%) and those working in management areas, such as budgeting, logistic and personnel management. 
Figure 2

\section{Aspects of the Government Structure}

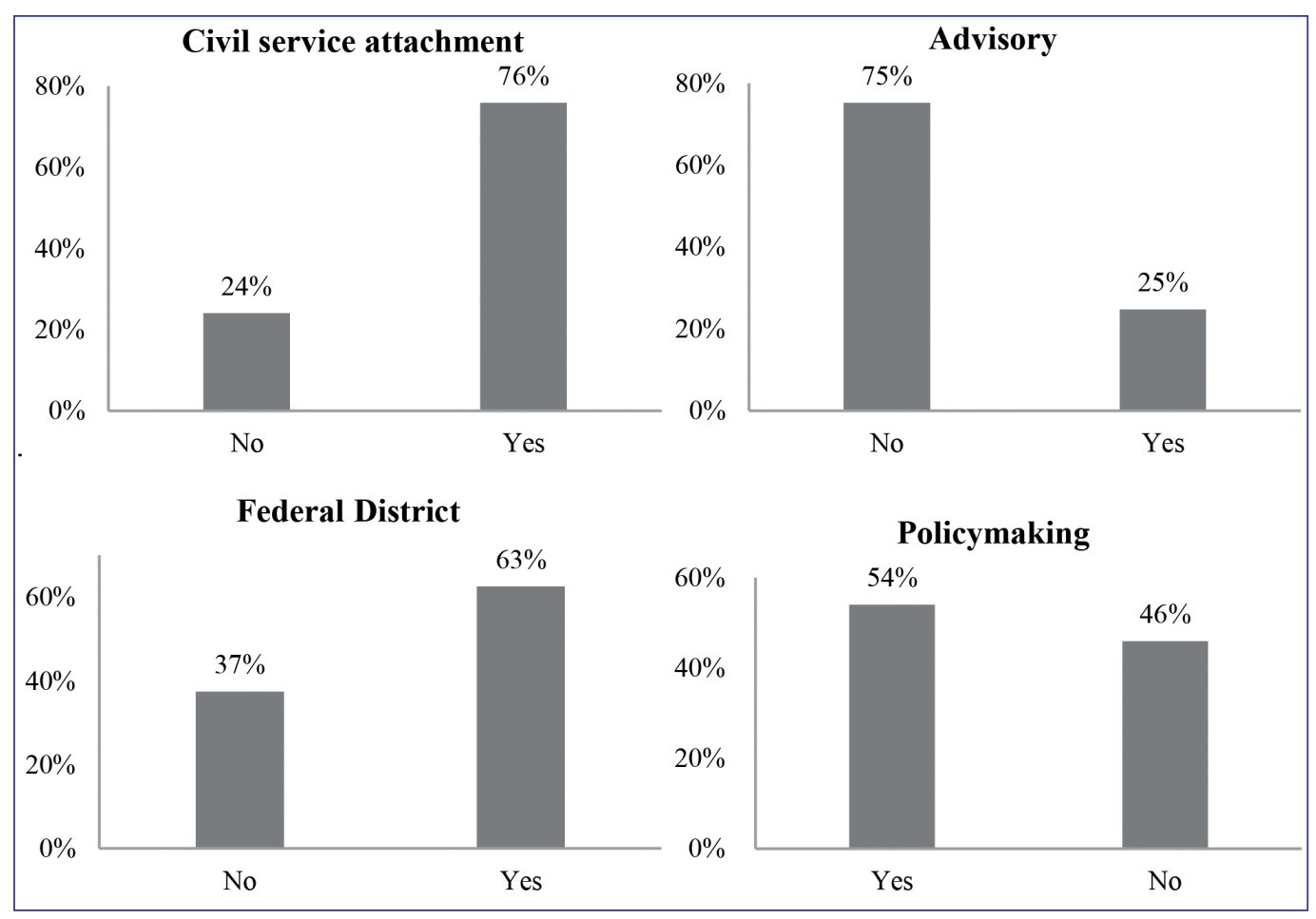

Source: Elaborated by the authors based on Mid-level Bureaucrats Survey.

These findings reinforce one of the conclusions often found in Brazilian literature, regarding the positions filled by appointment (D'ARAÚJO and LAMEIRÃO, 2011; PRAÇA, FREITAS and HOEPERS, 2011; BARBERIA and PRAÇA, 2014): the vast majority of bureaucrats who hold these kinds of positions are career civil servants, professionalized and well qualified who have many responsibilities in the formulation and implementation of public policies, rather than in advising in the decision making process..

Finally, the variation of the respondents according to the DAS level and the sector can be visualized in Figure 3 below. The distribution of positions filled by appointment among the different sectors varies. Social and economic sectors have a higher concentration of lower level DAS ( 1 to 3 ), while the infrastructure sector has higher DAS levels (4 and 5). The proportion found for the sample was also quite similar to the proportion of the DAS levels in the population in the federal government (ENAP, 2014), 


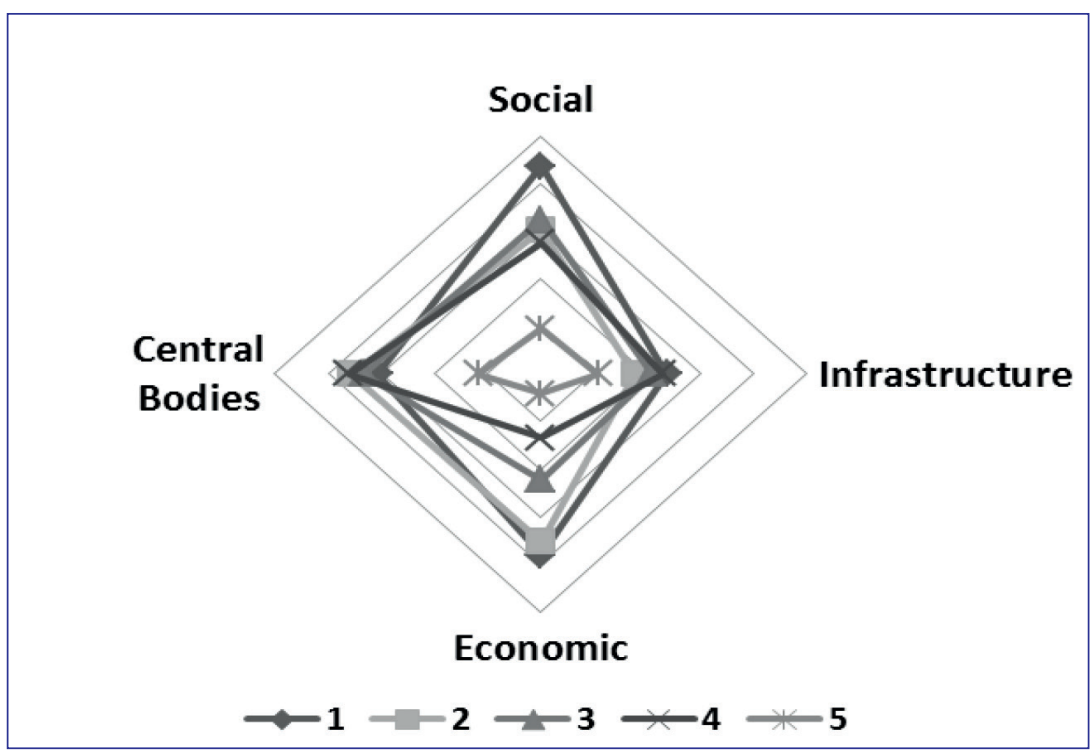

Source: Elaborated by the authors based on Mid-level Bureaucrats Survey.

\section{PERFORMANCE DETERMINANTS}

\section{Indexes of Performance}

The exploratory analysis reinforces the premise of mid-level bureaucrats' heterogeneity. However, performance is a complex concept that may be assumed by different approaches. In order to deepen the understanding of the MLB's performance, this article develops two analytical strategies: i) build composite indicators that objectively measure the MLBs degree of relationship and complexity level of activities and; ii) use a regression model to test hypotheses regarding the determinants of performance. Synthetic indicators were elaborated for two dimensions: Index of MLB Relationships (IBR) and Index of MLB Activities (IBA), based on the survey database previously discussed (ENAP, 2014). The research employs principal component analysis (PCA) to formulate these variables. ${ }^{2}$ Generally, composite indexes aim to summarize complex and multidimensional subjects helping to interpret, classify and rank units of analysis in a particular case.

First, an original frame was chosen, identifying the factors that best represent the analyzed subject. In this case, the frequency of bureaucrat's work relationships with a variety of actors and the frequency of a range of activities' performed throughout a year, were used.

The second step was the selection of primary data, which had been transformed to allow comparisons. This means that the frequencies of responses were converted into numbers from two questions of the survey. The work relationship question: thinking about the work routine of your current position (consider the last year), indicate how often you interact (negotiate, send and receive orders, resolve, request information, etc.) with governmental and non-governmental actors (all of them are described in the appendix). The activity question: thinking about your work routine in this current position (consider the last 12 months), indicate how often you perform the following activities (the list includes ten activities, detailed in table 4 in the appendix).

${ }^{2}$ The breakdown of how the indexes were formed is detailed in the appendix. 
After running the principal component analysis, the indexes scores were normalized to range from 0 to 100 , the greater the index the higher degree of relationship or the level of complexity of the activities the MLBs perform. The following figures illustrate the distribution of these indicators and reinforce the assumption of heterogeneity of MLBs performance. The box plots show in both cases some symmetry, which is reflected in their close standard deviations (around 13), and low number of outliers (the descriptive statistics of all variable are detailed in table 2 of the appendix). It is also evident that their average values are different, IBA (69) and IBR (55), however they are not comparable since the primary indicators used to build them were different. Although the distributions of indexes (over seven thousand cases in each box) are symmetric, showing a similar pattern of diversity in their interactions inside and outside federal government and the complexity of their activities. Put differently, while the majority of the IBA indexes (except the outliers) vary from 37 to 100, the majority of the IBR indexes oscillate from 21 to 85.

\section{Figure 4}

\section{IBA and IBR Distribution}

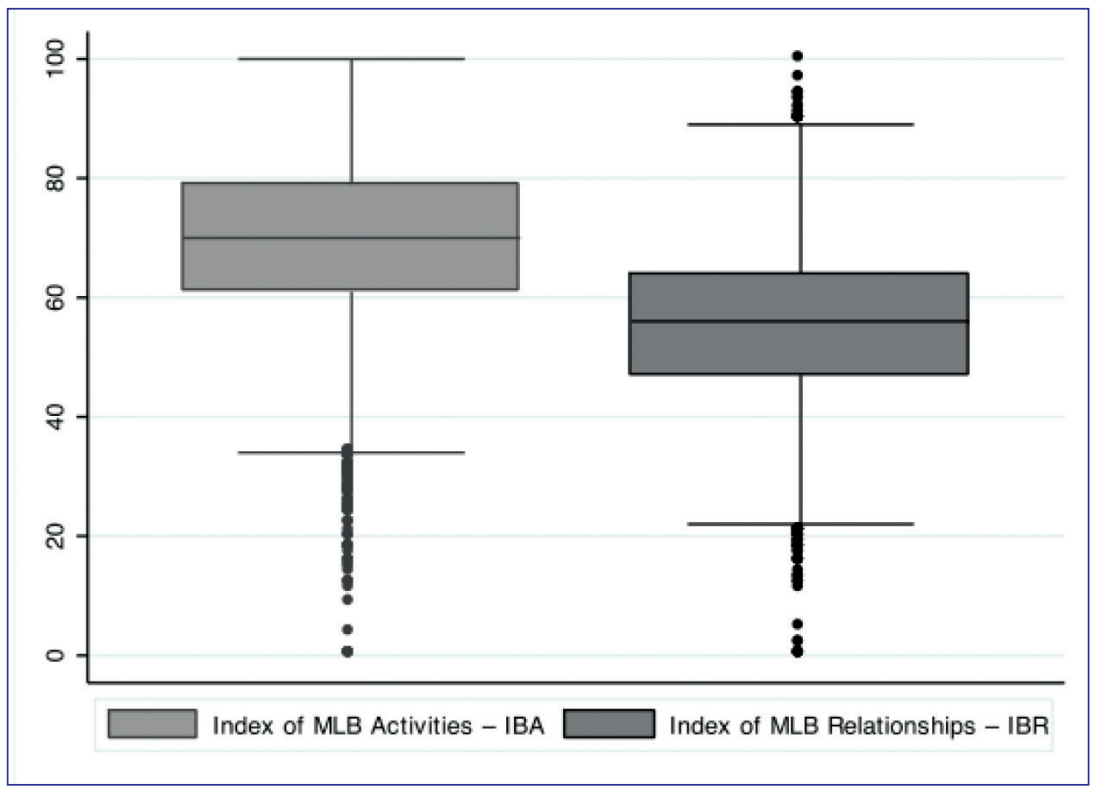

Source: Elaborated by the authors based on Mid-level Bureaucrats Survey.

\section{MODEL}

Mid-level bureaucrats in federal government have quite different profiles, backgrounds, level of influence, among other aspects, as discussed in the previous section. They also perform in distinctive ways in the public service. Therefore, new questions arise. What factors determine the variance of the degree of mid-level bureaucrats' work relationships? What characteristics affect the complexity level of activities performed by MLBs? Are these performance determinants influenced by the government structure factors, such as the level of hierarchical posts, or by individual factors, such as the management experience?

To answer these questions, multivariate analysis was employed using the two composite indicators described above, as dependent variables of the statistical models.

On the right side of the model, the variables are also from the Mid-level Bureaucrats Survey (ENAP, 2014), divided in two groups: i) those related to individual features of the civil servant and; ii) those grounded on the structure aspects of the government. So, the hypotheses of this research are:

H1a: The degree of the mid-level bureaucrat's work relationship (intra, intergovernmental and non- governmental) is affected by the individual characteristics of these actors. 
$\mathrm{H} 1 \mathrm{~b}$ : The complexity level of activities performed by the mid-level bureaucrats is influenced by the individual characteristics of these actors.

Individual variables were the first used to test these hypotheses. The mid-level bureaucrat's background can be a determining factor. Hence, the model includes two continuous variables, measured in years, which describe this dimension: public experience and management experience, both in federal administration. It is expected that the more experience the MLB has, the broader their network and the greater the list of activities.

The literature states that the ability to influence policy decisions is a crucial feature of these bureaucrats (CURRIE and PROCTER, 2005; KURATKO, IRELAND, COVIN et al., 2005; KELLY and GENNARD, 2007). The test now is to see how important this is to MLBs performance. Therefore, the second independent variable is influence, a dichotomous dummy created from the survey question about how frequent the MLB's ideas are considered in the decision-making process. Continuing on the individual level, the age and level of education of the civil servants are employed in the models. The latter varies from 1 (elementary school) to 6 (PhD). It is assumed that younger and more formally educated mid-level bureaucrats tend to be more connected and perform a higher number of activities.

The second group of variables is related to aspects embedded in the government framework, and then the hypotheses are:

H2a: The degree of the mid-level bureaucrat's work relationships (intra, intergovernmental and non-governmental) is affected by the government's structure factors.

$\mathrm{H} 2 \mathrm{~b}$ : The complexity level of activities performed by mid-level bureaucrats is influenced by the government's structure factors.

The first structure variable is the level of the positions filled by appointment held by the respondent. In theory, higher positions tend to reflect more responsibilities, so it is expected that the higher the DAS (varying from 1 to 5 ) the higher the IBR and IBA indexes because of the complexities of the post in managing policies. The dummy variable 'advisory' differentiates the DAS by its types, since classification can include two kinds of functions: management or executive positions (coordinator, director, etc.) and advisory positions. The expectation is that the bureaucrats in management positions interact more and has a wider range of activities than those in advisory positions. Similarly, civil service attachment aims to test whether being part of a permanent career in the public sector affects the MLB's performance, as they normally have more roots with the civil service and a long-term perspective.

Based on the classification of government, the models test if the bureaucrats who work in the different policy areas, in ministries and agencies of social, infrastructure and economic sectors, perform differently. The same logic applies to MLBs who are in charge of policymaking or direct policy delivery. It is expected that they interact more and are involved in a broader set of activities than bureaucrats in management areas, usually responsible for budgeting, logistic and personnel management.

The dummy FD is used to analyze if there are performance differences among bureaucrats in the Federal District and another twenty-six states. The six variables are dichotomous, varying from 0 to 1 . Therefore, the model can be described as follows:

$\mathrm{IBR}_{\mathrm{i}}$ or IBA $\mathrm{IB}_{\mathrm{i}}=\beta_{0+} \beta_{1}$ Public Experience ${ }_{\mathrm{i}+} \beta_{2}$ Management Experience $_{\mathrm{i}+} \beta_{3}$ Influence $_{i+} \beta_{4}$ Age $_{i+} \beta_{5}$ Education $_{\mathrm{i}+} \beta_{6} \mathrm{DAS}_{\mathrm{i}+} \beta_{7}$ Advisory $_{\mathrm{i}}$ ${ }_{+} \beta_{8}$ Civil Service Attachment ${ }_{i+} \beta_{9}$ Social $_{i+} \beta_{10}$ Infrastructure $_{i+} \beta_{11}$ Economic $_{i+} \beta_{12}$ Policymaking $_{+} \beta_{13}$ FD $+u_{i}$

\section{RESULTS AND ANALYSIS}

The models results, from Ordinary Least Square regression (OLS) using cross-sectional data, are interesting in different ways. Table 3 (shown in the appendix) presented the estimated coefficients, standard errors in parentheses and the models coefficients of determination. Importantly, due to the large sample (7094 observations), T-test and F-test are valid asymptotically, even with some variables not statistically significant; overall, significance of the regressions is confirmed (WOOLDRIDGE, 2006). After the regression, a check for multicollinearity was carried out and the results proved that the degree of collinearity among the independent variables is not worrisome.

Initially, although the coefficients of determination $\left(R^{2}\right)$ are not so expressive, based on the variables' estimates; relevant assumptions were tested and discussed. Secondly, it is also noticeable how alike the effects are of most of the independent variables on IBR and IBA indexes. 
Regarding the first hypotheses about the effects of MLBs' individual characteristics on performance, the empirical results are intriguing. The variables relating to professional history have opposite results. While having experience in the federal public administration negatively affects the indexes, which means that the more years in office the less connected and less activities are found. On the other hand, managerial experience tends to result in higher IBR and IBA indexes. However, even statistically significant, the coefficients have negligible impacts, ceteris paribus.

The estimates of age in both models suggest that younger MLBs have more complex performance, even though the coefficients are not so high. On the contrary, the educational level shows statistically and substantively relevance, especially in the IBA index. Keeping the other factors constant, a difference of professionals with elementary and PhD levels of education, on average, represent a growth of approximately 13 points in this dimension's scores.

The most intense effect of the MLBs' individual characteristics comes from the influence variable, since it is not only statistically significant in both models, but also has the highest coefficients.

Table 1

MLB's Performance determinants

\begin{tabular}{|c|c|c|}
\hline & $\begin{array}{l}\text { IBR } \\
\text { (1) }\end{array}$ & $\begin{array}{l}\text { IBA } \\
\text { (2) }\end{array}$ \\
\hline \multirow{2}{*}{ Public Experience } & $-0.04 *$ & $-0.08^{* * *}$ \\
\hline & $(0.021)$ & $(0.021)$ \\
\hline \multirow{2}{*}{ Management Experience } & $0.18^{* * *}$ & $0.25^{* * *}$ \\
\hline & $(0.028)$ & $(0.028)$ \\
\hline \multirow{2}{*}{ Influence } & $5.56^{* * *}$ & $7.0^{* * *}$ \\
\hline & $(0.3)$ & $(0.299)$ \\
\hline \multirow{2}{*}{ Age } & $-0.16^{* * *}$ & $-0.14 * * *$ \\
\hline & $(0.017)$ & $(0.017)$ \\
\hline \multirow{2}{*}{ Education } & $0.72^{* * *}$ & $2.7^{* * *}$ \\
\hline & $(0.158)$ & $(0.157)$ \\
\hline \multirow{2}{*}{ DAS } & $2.05^{* * *}$ & $2.146^{* * *}$ \\
\hline & (0.128) & (0.128) \\
\hline \multirow{2}{*}{ Advisory } & -0.136 & $-0.747 *$ \\
\hline & $(0.337)$ & $(0.337)$ \\
\hline \multirow{2}{*}{ Civil Service Attachment } & $-1.93^{* * *}$ & 0.67 \\
\hline & $(0.354)$ & $(0.353)$ \\
\hline \multirow{2}{*}{ Social } & $2.2^{* * *}$ & $1.4^{* * *}$ \\
\hline & $(0.356)$ & $(0.356)$ \\
\hline \multirow{2}{*}{ Infrastructure } & $1.41^{* * *}$ & 0.14 \\
\hline & $(0.381)$ & $(0.381)$ \\
\hline
\end{tabular}


Continue

\begin{tabular}{|c|c|c|}
\hline & $\begin{array}{l}\text { IBR } \\
\text { (1) }\end{array}$ & $\begin{array}{l}\text { IBA } \\
\text { (2) }\end{array}$ \\
\hline \multirow{2}{*}{ Economic } & $1.72 * * *$ & 0.35 \\
\hline & $(0.451)$ & $(0.451)$ \\
\hline \multirow{2}{*}{ Policymaking } & $3.92 * * *$ & $2.39 * * *$ \\
\hline & $(0.296)$ & $(0.295)$ \\
\hline \multirow{2}{*}{ DF } & -0.12 & $-0.76^{*}$ \\
\hline & $(0.325)$ & $(0.325)$ \\
\hline \multirow{2}{*}{ Constant } & $52.42 * * *$ & $56.05 * * *$ \\
\hline & $(0.925)$ & (0.923) \\
\hline Observations ( $\mathrm{n}$ ) & 7095 & 7095 \\
\hline Adjusted $\mathrm{R}^{2}$ & 0.18 & 0.25 \\
\hline
\end{tabular}

Source: Elaborated by the authors based on Mid-level Bureaucrats Survey. Note: Standard errors in parentheses $* p<0.05, * * p<0.01, * * * p<0.001$.

In this sense, some scholars have investigated the necessary features to foster MLBs' capacity to influence on the decisionmaking process. They conclude that variables such as combination of technical and specialized insertion and management skills in the organizational structure; level of conflict with professionals that are responsible for daily operations; sensitivity to understand, objectively, the strategic context of the organization, mid-level bureaucrats who often have their ideas considered in the decision-making process have, on average, 5.5 points in the relationship index and 7 points in the activity index, higher than those less influential, holding the other factors constant.

The statistical models provide estimates that help to confirm the first two hypotheses that individual characteristics, especially age, level of educational and capacity to influence decisions, affects the degree of relationship inside and outside the government and the complexity level of activities. This suggests that in a context of more complex policies, involving different kinds of actors inside and outside the state, the dimension of bureaucrats' relationships is a determinant of their performance. It also suggests that nowadays the state is operating in a very specific dynamic that demands high qualifications and bureaucratic knowledge.

Moving to the second group of hypotheses focused on the impact of the government's structure factors, one of the most striking effects is the hierarchical positions. The level of DAS, as expected, influences the bureaucrats' performance in both models with very similar estimates. These impacts can be better seen in Figure 4 below, that project the estimated relationships between the indexes and the DAS level. In both cases, the coefficients effects are quite intense. In objective terms, a variation between DAS1 and DAS5 represents, on average, increase of more than 10 points in the IBR index, almost $40 \%$ of the index average, keeping the other factors constant. The effects activities are even higher. In this case, a change from DAS 1 to 5 affects the IBA index by almost 11 points, all other variables being equal. 


\section{Figure 5}

\section{Relationships between MLB' IBR/IBA indexes and DAS}

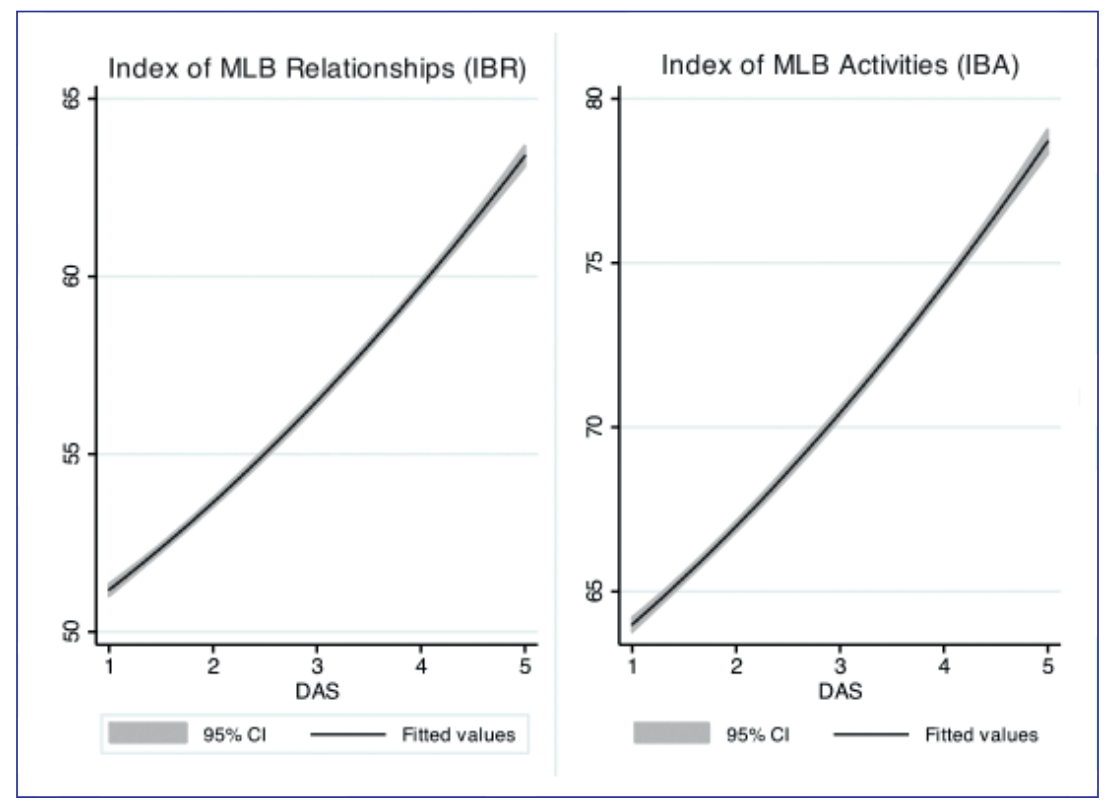

Source: Elaborated by the authors based on Mid-level Bureaucrats Survey.

Occupying the commissioned position of advisor does not differentiate the level of bureaucrats' working relationship. On the contrary, the significant and negative coefficient in model 2 outlines the fact that advisors in the mid-level bureaucracy tend to perform less activities than managers, although substantively it is a small estimate effect.

Surprisingly, civil service attachment reflects on a lesser-connected bureaucrat. This result is interesting because it diverges the idea that MLBs with permanent careers in the public sector would be more capable of articulating with other actors (intra, intergovernmental and non-governmental), given their long term perspective in the federal government. In fact, a tenured public servant, on average, reduces by almost 2 points in the relationship indexes, while in model 2 this variable has no significant effect.

Concerning the policy sectors, the empirical results suggest that working in the social, infrastructure and economics ministries/agencies matters in terms of the performance dimensions analyzed. However, the effects are quite distinct. First, it is clear that MLBs working with social policy tend to articulate more and have a broader set of activities than in other sectors of the government. The models also show significant estimates for the economic and infrastructure sectors, however, to a lesser extent in the social area. One possible explanation for this may reside in the fact that the latter usually deals more directly with beneficiaries and, consequently, must interact more and undertake a variety of activities in public administration. 
As for the MLB's routine tasks, the results converge with expectation; the mid-level bureaucrats involved in policymaking have a broader range of interactions and activities than those working in management areas. Finally, there are no significant differences between bureaucrats that work in the Federal District or in other states, shown in the estimates that are not statistically significant (model 1 ) or very slight (model 2).

As for the analysis of the first hypotheses, the models contribute to confirm that government's structure factors also impact on mid-level bureaucrat's performance, however, to a lesser extent than expected. While advisory posts and civil service attachment are not important predictors, policy sectors, type of routine tasks and, primarily, level of hierarchical positions (DAS) do matter in explaining the heterogeneous performance of this segment of the State.

Overall, the models results show that the mid-level bureaucrats' performance (relationship and activity) is affected both by the government's structure factors and by individual characteristics. However, the variables effects vary considerably. The empirical evidence suggests that MLBs tend to be more connected and perform more activities as they hold higher positions filled by appointment, have a higher level of education and capacity to influence decision processes and work directly with policymaking, especially social policy.

In this sense, it is clear - as demonstrated in previous researches - the mid-level bureaucrats' skills of interacting inside and outside government, as well as performing complex activities. They also tend to have a specific profile, position in government and access to certain networks. Nowadays these aspects have become even more strategic, considering that, under the "Era of governance", the MLB is requested not only to improve its performance inside the public organization, but also to develop skills that deal with the new trends of networking, partnerships, collaboration and social participation.

\section{FINAL REMARKS}

This article aimed to deepen the understanding of mid-level bureaucrats' performance in order to contribute both to the incipient literature on the subject and to the empirical knowledge of Brazilian public administration.

Based on the current theoretical debate, the research allows comprehending the MLB's heterogeneity in Brazilian federal government, which, in turn, helps to provide accurate information about the structure and dynamics of the government in Brazil. At the same time, the analyses allowed to advance two of the crucial aspects of the mid-level bureaucrats' performance: work relationships and the complexity of their activities. As noted in the literature review, the relational dimension of MLBs is, first, one of the determinants of their performance and, secondly, one of the largest gaps - and this research addresses part of this gap - in the current knowledge about these relevant state actors. In addition, as noted in the literature and considering the new context of policy implementation, one of the main determinants of performance is the ability of the bureaucrats to establish and conduct relationships with different actors.

In order to analyze performance, taking the dimension 'relationship' into consideration, the study employed diversified and sophisticated analytical strategies to cope with the bureaucrats' complex context, presenting interesting results.

Regarding the diversity of bureaucrats, the exploratory analysis indicates that there are quite different profiles inside the federal government, with differences in age, professional background, education, capacity to influence, functions and activities. The huge number of possible combinations of characteristics may indicate that there was a transition of MLBs' profile, with the presence of a 'more negotiator' profile in the younger generations (in which communication is a large part of their responsibilities), rather than the 'more technical and operational' profile of the older generations. Furthermore, it is possible to think of the assumption that government sectors count on different profiles of mid-level bureaucrats and, consequently, different dynamics in policymaking. These results are relevant to demonstrate the comprehensiveness of both the federal bureaucracy and the role played by mid-level bureaucrats.

As shown in previous researches, and reinforced by the data collected and analyzed in this study, the understanding of the mid-level bureaucrats assumes building typologies to contribute to the progress in classifying the MLBs in different profiles and performances. The results obtained help to deconstruct the common sense perception that the majority of positions 
filled by appointment in the federal government are filled according to partisan interests and not based on meritocracy. The study's findings point out the opposite, showing that there are different groups in these positions and the largest of them, for instance, is formed by civil servants with permanent contracts and high qualifications and experience. These findings reinforce what is already shown by the literature in researches such as D'Araújo and Lameirão (2011), Praça, Freitas and Hoepers (2011), Barberia and Praça (2014) and Cavalcante and Carvalho (2017), which demonstrate that the professional experience and competencies are the main determinants to be appointed for these positions.

The results demonstrate the importance of the public administration in designing human resource management policies in order to address this diversity and improve this aspect of the state capacity in policymaking.

Concerning the article's main goal, the determinants of the MLBs' performance depicted by the degree of their work relationship and the level of complexity of their activities, the regression models confirm the research hypotheses that these dimensions are intensively affected by individual features and government structure factors. However, the effects are quite diverse among the explanatory variables.

Therefore, the article's findings show that in order to understand and, more importantly, to improve bureaucrats' capacity to deal with the increasing challenges faced by the public sector, a comprehensive approach must be employed. In other words, it is imperative not only to focus on the individual aspects of the mid-level bureaucrat, but also on the public administration structure in order to train and prepare civil servants to work more interactively in a dynamic governance framework. This becomes central in a context of state action increasingly focused on the idea of governance, in which public policies are shaped by the interaction between multiple actors. In this context of policy implementation in governance, the performance of bureaucrats in a relational perspective becomes decisive.

In this context, this article paves the way to a fruitful research agenda that is threefold. First, some of the results raise new research questions that deserve further investigation, such as why do some policy sectors have stronger effects on performance than others? Why are younger bureaucrats more connected and perform more complex activities? To what extent do the hierarchical positions tend to interfere in the capacity to influence the decision-making process? To answer these questions, qualitative methods are recommended.

A second route points to advancing the investigation including other variables in order to create an original typology of MLB, using cluster analysis. Future research may focus on comparative approaches of the performance, profile and background of this bureaucrat with other segments of the bureaucracy, such as top managers and street-level bureaucrats. Third and finally, although the literature has emphasized how important mid-level bureaucrats are for policymaking, there is still a lack of research on how they operate and the outputs of their performance, especially in Brazil. 


\section{REFERENCES}

ABERS, R. N. Ativismo na burocracia? O médio escalão do Programa Bolsa Verde. In: CAVALCANTE, P.; LOTTA, G. (Ed.). Burocracia de médio escalão: perfil, trajetória e atuação. Brasília: ENAP, 2015. p. 143-175.

ABERS, R. N.; KECK, M. E. Practical authority: Agency and institutional change in Brazilian water politics. Oxford University Press, 2013.

ALEXANDER, D.; LEWIS, J. M.; CONSIDINE, M. How politicians and bureaucrats network: a comparison across governments. Public Administration, v. 89, n. 4, p. 1274-1292, 2011.

BENZÉCRI, J.-P. Correspondence analysis handbook. New York: Marcel Dekker Inc., 1992.

BEVIR, M.; RHODES, R. A.W. The state as cultural practice. Oxford: Oxford University Press, 2010.

CAVALCANTE, P.; LOTTA, G. Burocracia de Médio Escalão: perfil, trajetória e atuação. Brasília: ENAP, 2015.

CAVALCANTE, P.; CARVALHO, P. Profissionalização da burocracia federal brasileira (1995-2014): avanços e dilemas. Revista de Administração Pública, v. 51, n. 1, p. 1-26, 2017.

CHAREANPUNSIRIKUL, S.; WOOD, R. C. Mintzberg, managers and methodology: some observations from a study of hotel general managers. Tourism Management, v. 23, n. 5, p. 551-556, 2002.

CHRISTENSEN, T.; LAEGREID, P. The whole-of-government approach to public sector reform. Public administration review, v. 67, n. 6, p. 1059-1066, 2007.

CURRIE, G.; PROCTER, S. J. The antecedents of middle managers' strategic contribution: The case of a professional bureaucracy. Journal of management studies, v. 42, n. 7, p. 1325-1356, 2005.

DALTON, M. Men who manage. New York: John Wiley \& Sons, 1959.

DEMIR, T.; REDDICK, C. G. Understanding Shared Roles in Policy and Administration: An Empirical Study of Council-Manager Relations. Public Administration Review, v. 72, n. 4, p. 526-535, 2012.

FOSSEST $\varnothing \mathrm{L}, \mathrm{K}$. et al. Managing institutional complexity in Public Sector Reform: Hybridization in front-line service organizations. Public Administration, v. 93, n. 2, p. 290-306, 2015.

GREENACRE, M. Correspondence analysis in practice. Boca Raton: CRC press, 2017.

GREENACRE, M. Theory and applications of correspondence analysis. London: Academic Press, 1984.

GREVE, C.; LAEGREID, P.; RYKKJA, L. H. The Nordic Model Revisited: Active Reformers and High Performing Public Administrations. In: GREVE, C.; LAEGREID, P.; RYKKJA, L. H. (Ed.). Nordic Administrative Reforms: Lessons for Public Management. Basingstoke: Palgrave Macmillan, 2016. p. 189-212.

HAIR, J. F. et al. Análise Multivariada de Dados. 5. ed. Porto Alegre: Bookman, 2005.

HOWLETT, M. Public managers as the missing variable in policy studies: An empirical investigation using Canadian data. Review of Policy Research, v. 28, n. 3, p. 247-263, 2011.

HUISING, R.; SILBEY, S. S. Governing the gap: Forging safe science through relational regulation. Regulation \& Governance, v. 5, n. 1, p. 14-42, 2011.
JOHANSSON, V. Negotiating bureaucrats. Public Administration, v. 90, n. 4, p. 1032-1046, 2012.

KAUFMAN, $\mathrm{H}$. The forest ranger: A study in administrative behavior Londres: Routledge, 1960.

KEISER, L. R. Understanding Street-Level Bureaucrats' Decision Making: Determining Eligibility in the Social Security Disability Program. Public Administration Review, v. 70, n. 2, p. 247-257, 2010.

KELLY, J.; GENNARD, J. Business strategic decision making: the role and influence of directors. Human Resource Management Journal, v. 17, n. 2, p. 99-117, 2007.

KURATKO, D. F. et al. A Model of Middle-Level Managers' Entrepreneurial Behavior. Entrepreneurship theory and practice, v. 29, n. 6, p. 699716, 2005.

LIPSKY, M. Street-level bureaucracy: dilemmas of the individual in public services. 30. ed. New York: Russell Sage Foundation, 2010.

LOTTA, G. S. Implementação de políticas públicas: o impacto dos fatores relacionais e organizacionais sobre a atuação dos burocratas de nível de rua no Programa Saúde da Família. 2010. Thesis (Doctor Degree in Political Science) - Departamento de Ciência Política, Universidade de São Paulo, São Paulo, 2010.

LOTTA, G. S.; PIRES, R. R. C.; OLIVEIRA, V. E. Burocratas de médio escalão: novos olhares sobre velhos atores da produção de políticas públicas. Revista do Serviço Público, v. 65, n. 4, p. 463-492, 2014.

MENICUCCI, T.; GONTIJO, J. G. L. Gestão e políticas públicas no cenário contemporâneo: tendências nacionais e internacionais. Rio de Janeiro: Fiocruz, 2016.

MEYER, R. E. et al. Of bureaucrats and passionate public managers: Institutional logics, executive identities, and public service motivation. Public Administration, v. 92, n. 4, p. 861-885, 2014.

MINTZBERG, H. The nature of managerial work. New York: Harper \& Row, 1973.

NENADIC, O.; GREENACRE, M. Correspondence analysis in R, with two-and three-dimensional graphics: The ca package. Journal of Statistical Software, v. 20, n. 3, May 2007.

OLIVEIRA, V. E. Instituições, burocracia e produção de políticas públicas: o caso da política estadual de saúde. In: ENCONTRO ANUAL DA ANPOCS, 33, 2009. Anais... Caxambu, MG, 2009.

OLIVEIRA, V. E.; ABRUCIO, F. L. Entre a política e a burocracia: a importância dos burocratas de médio escalão para a produção de políticas públicas em saúde e educação. In: ENCONTRO ANUAL DA ANPOCS, 35, 2011. Anais... Caxambu, MG, p. 347-375, 2011.

OSBORNE, S. (Ed.). The new public governance: Emerging perspectives on the theory and practice of public governance. Londres: Routledge, 2010.

PIRES, R. Burocracias, gerentes e suas "histórias de implementação": narrativas do sucesso e fracasso de programas federais. In: FARIA, C. A. P. (Ed.). Implementação de políticas públicas: teoria e prática. Belo Horizonte: Editora PUC Minas, p. 182-220, 2012.

PIRES, R. Por Dentro do PAC: arranjos, dinâmicas e instrumentos na perspectiva dos seus operadores. In: CAVALCANTE, P.; LOTTA, G. (Ed.). Burocracia de Médio Escalão. Brasília: ENAP, 2015. 
POLLITT, C.; BOUCKAERT, G. Public Management Reform: A comparative analysis-new public management, governance, and the Neo-Weberian state. Oxford: Oxford University Press, 2011

SCANDAR NETO, W. J. Síntese que organiza o olhar: uma proposta para construção e representação de indicadores de desenvolvimento sustentável e sua aplicação para os municípios fluminenses. Dissertation (Master Degree in Population Studies and Social Research) - Escola Nacional de Ciências Estatísticas, Instituto Brasileiro de Geografia e Estatística, Rio de Janeiro, 2006.

NETO, W. J. S.; DE MARTINO JANNUZZI, P.; DO NASCIMENTO SILVA, P. L. Sistemas de Indicadores ou Indicadores Sintéticos: do que precisam os gestores de programas sociais? In: ENCONTRO NACIONAL DE ESTUDOS POPULACIONAIS, 16, 2016. Anais...Caxambu: ENEP, p. 1-14, 2016.

VAKKURI, J. Struggling with ambiguity-public managers as users of NPM instruments. Public Administration, v. 88, n. 4, p. 999-1024, 2010.

VIE, O. E. Have post-bureaucratic changes occurred in managerial work? European Management Journal, v. 28, n. 3, p. 182-194, 2010.

WILSON, J. Q. Varieties of Police Behavior: The Management of LaW and Order in Eight Communities, With a New Preface by the Author. Cambridge, Massachusetts: Harvard University Press, 1968.

WOOLDRIDGE, J. M. Introdução à econometria: uma abordagem moderna. São Paulo: Pioneira Thomson Learning, 2006. 


\section{APPENDIX}

\section{Indexes of Mid-level Bureaucrats' activities and work relationships}

This section presents the methodology adopted to prepare the synthetic Index of MLB 'Relationships' (IBR) and Index of MLB 'Activities' (IBA). Synthetic index is used to summarize complex or multidimensional issues, facilitate interpretations as well as to classify and organize information in order to assist evaluations and/or decision-making (SCANDAR NETO, 2006). The construction process involves stages in which some decisions must be made (SCANDAR NETO, JANNUZZI and SILVA, 2008).

Initially, an original framework was adopted including the factors that best represent the frequency of bureaucrats' relationship with governmental and non-governmental actors and the frequency of activities' performed over a year. The second step was the selection of primary data, transformed in order to allow comparisons. The frequencies of responses were converted into numbers from question P13 and P14 of the survey - Always (5); Often (4); Sometimes (3); Rarely (2); and Never (1).

The question for relationship was: thinking about the work routine of your current position (consider the last year), indicate how often you interact (negotiate, send and receive orders, resolve, request information, etc.) with governmental and nongovernmental actors. The relationship of these actors/institutions (IBR primary indicators), are in Table 3. The question for activity was: thinking about your work routine in this current position (consider the last 12 months), indicate how often you perform the following activities, listed in table 4.

In the next step, the Principal Component Analysis method (PCA) was employed. PCA is a type of factor analysis, which identifies factors that objectively point to the aggregation and reduction of complex measures. The method provides less loss of explanatory power of the original data and a lesser degree of subjectivity of the researcher (HAIR, ANDERSON, TATHAM et al., 2005). The main purpose is to create new variables that are linear combinations of the primary variables. Thus, unlike the arbitrary definition of weights, the methodology takes advantage of the correlation between indicators and creates an index corresponding to a weighted average of these variables.

When the indexes were built, they were transformed, aiming to normalize the values within a range from 0 to 100 , using the following formula:

$$
I S_{i}^{X}=\left[\frac{X i-X \min }{X \max -X \min }\right] * 100=0 \ldots 100
$$

where,

IS = Synthetic Index

$\mathrm{X}_{\mathrm{i}}=$ Observed Index

$\mathrm{X}_{\min }=$ Minimum value

$\mathrm{X}_{\max }=$ Maximum value

Finally, Table 2 and 3 include the percentage variation of the first component and the respective factor loadings used for the calculation of indexes, separated by the dimension indicators: 
Table 2

Variables descriptive statistics

\begin{tabular}{|c|c|c|}
\hline Variable & Mean & Standard deviation \\
\hline IBR & 0,555 & 0,13 \\
\hline IBA & 0,692 & categorical variable \\
\hline DAS & categorical variable & dichotomous variable \\
\hline Advisory & dichotomous variable & dichotomous variable \\
\hline Federal administration bond & dichotomous variable & dichotomous variable \\
\hline Social & dichotomous variable & dichotomous variable \\
\hline Infrastructure & dichotomous variable \\
\hline Economic & dichotomous variable & 11,359 \\
\hline FD & dichotomous variable & 7,648 \\
\hline Public experience & 14,473 & dichotomous variable \\
\hline Management experience & 6,664 & dichotomous variable \\
\hline Policymaking & dichotomous variable & 10,857 \\
\hline Influence & dichotomous variable & categorical variable \\
\hline Age & categorical variable & \\
\hline
\end{tabular}

Source: Elaborated by the authors based on Mid-level Bureaucrats Survey.

Table 3

List of variables and loadings of the first component

\begin{tabular}{|c|c|c|}
\hline & Primary Indicator & Eigenvalue \\
\hline \multirow[t]{13}{*}{ Index of MLB Relationships (IBR) } & Superiors & \multirow[t]{3}{*}{1.4} \\
\hline & Subordinates & \\
\hline & Colleagues of the same hierarchical level & \\
\hline & $\begin{array}{l}\text { Other agencies in government's structure } \\
\text { (except Civil Office) }\end{array}$ & \multirow[t]{6}{*}{2.74} \\
\hline & Civil Office & \\
\hline & Politicians & \\
\hline & $\begin{array}{c}\text { Control agencies (General Comptroller of the } \\
\text { Union, Federal Court of Accounts) }\end{array}$ & \\
\hline & Judiciary bodies & \\
\hline & States and municipalities & \\
\hline & International organizations & \multirow[t]{4}{*}{2.45} \\
\hline & Media & \\
\hline & Civil society & \\
\hline & Private companies & \\
\hline
\end{tabular}

Source: Elaborated by the authors based on Mid-level Bureaucrats Survey. 
Table 4

List of variables and loading of the first component

\begin{tabular}{|c|c|c|}
\hline & Primary Indicator & Eigenvalue \\
\hline \multirow{10}{*}{ Index of MLB Activities (IBA) } & $\begin{array}{l}\text { Contacts and individual conversations (e.g. } \\
\text { phone calls, clearances, etc.) }\end{array}$ & \multirow{10}{*}{3.55} \\
\hline & $\begin{array}{l}\text { Participate in meetings with internal agency } \\
\text { staff }\end{array}$ & \\
\hline & Attend meetings with external parties & \\
\hline & $\begin{array}{l}\text { Provide or validate data for of systems } \\
\text { information }\end{array}$ & \\
\hline & $\begin{array}{l}\text { Conduct research and studies (reading, } \\
\text { searching for information, consulting } \\
\text { experts) }\end{array}$ & \\
\hline & Business Travel & \\
\hline & $\begin{array}{l}\text { Produce and validate internal documents } \\
\text { (e.g. technical opinion, reports, plans, } \\
\text { spreadsheets and presentations) }\end{array}$ & \\
\hline & $\begin{array}{l}\text { Produce and validate normative documents } \\
\text { (e.g. drafts of decree resolutions or } \\
\text { ordinance or regulation) }\end{array}$ & \\
\hline & $\begin{array}{l}\text { Produce and validate external circulation of } \\
\text { documents (e.g. releases, flyers, brochures } \\
\text { and manuals) }\end{array}$ & \\
\hline & $\begin{array}{l}\text { Organize or participate in events } \\
\text { (conferences, lectures and congresses) }\end{array}$ & \\
\hline
\end{tabular}

Source: Elaborated by the authors based on Mid-level Bureaucrats Survey.

Pedro Luiz Cavalcante

PhD in Political Science from University of Brasília (UnB); Coordinator of Studies and State Policies and Democracy of the Institute for Applied Economic Research (IPEA), Brasília - DF, Brazil. E-mail: cavalcante.pedro@gmail.com

Gabriela Spanghero Lotta

PhD in Political Science from São Paulo University (USP); Assistant Professor at the Federal University of ABC, São Bernardo do Campo - SP, Brazil. E-mail: gabriela.lotta@gmail.com 